\title{
PENGARUH STRATEGI PEMBELAJARAN DENGAN PENGGUNAAN MEDIA EXELEARNING DAN KOMUNIKASI INTERPERSONAL TERHADAP HASIL BELAJAR IPA SISWA KELAS VIII SMP NEGERI DI KECAMATAN LIMA PULUH
}

\author{
Ardiles Lubis ${ }^{1}$, Efendi Napitupulu ${ }^{2}$ \\ Teknologi Pendidikan Pascasarjana Universitas negeri Medan \\ ardiles_lubis@yahoo.com ${ }^{1}$
}

\begin{abstract}
Abstrak: Penelitian ini bertujuan untuk mengetahui: (1) hasil belajar siswa yang diajarkan strategi pembelajaran inkuiri menggunakan media exelearning online dibandingkan siswa yang diajarkan strategi pembelajaran inkuiri menggunakan media exelearning offline; (2) hasil belajar siswa yang memiliki komunikasi interpersonal terbuka dibandingkan siswa yang memiliki komunikasi interpersonal tertutup; dan (3) interaksi antara strategi pembelajaran menggunakan media exelearning dan komunikasi interpersonal terhadap hasil belajar siswa. Metode penelitian adalah metode quasi eksperimen. Hasil penelitian menunjukkan: (1) hasil belajar IPA siswa yang diajarkan dengan strategi pembelajaran inkuiri menggunakan media exelearning online lebih tinggi dibandingkan hasil belajar siswa yang diajarkan dengan strategi pembelajaran inkuiri menggunakan media exelearning offline dengan besarnya pengaruh; (2) hasil belajar IPA siswa yang memiliki komunikasi interpersonal terbuka lebih tinggi dibandingkan hasil belajar IPA siswa yang memiliki komunikasi interpersonal tertutup dengan besarnya pengaruh; dan (3) terdapat interaksi antara strategi pembelajaran inkuiri menggunakan media exelearning dan komunikasi interpersonal terhadap hasil belajar IPA siswa.
\end{abstract}

Kata Kunci: strategi pembelajaran inkuiri, media exelearning online, strategi pembelajaran inkuiri, media exelearning offline, komunikasi interpersonal, IPA

\begin{abstract}
This study aims to determine: (1) the learning outcomes of students who are taught strategies exelearning inquiry learning using online media than students taught using the inquiry learning strategy exelearning offline media; (2) the learning outcomes of students who have interpersonal communication open than students who have closed interpersonal communication; and (3) the interaction between the learning strategy use exelearning media and interpersonal communication on student learning outcomes. The research method was quasi-experimental methods. The results showed: (1) the learning outcomes of students who were taught science by inquiry learning strategies using online media exelearning higher than student learning outcomes are taught strategies exelearning inquiry learning using offline media to the magnitude of influence; (2) Science learning outcomes of students who have interpersonal communication open higher than science learning outcomes of students who have interpersonal communication covered by the magnitude of the effect; and (3) there is no interaction between the strategy of inquiry learning using exelearning media and interpersonal communication on science student learning outcomes.
\end{abstract}

Keywords: inquiry learning strategies, online media exelearning, inquiry learning strategy, exelearning offline media, interpersonal communication, IPA

\section{PENDAHULUAN}

Hasil belajar siswa pada bidang studi fisika pada umumnya belum maksimal dan memuaskan, diduga karena proses pembelajaran kurang mendukung pemahaman anak didik, yaitu terlalu banyak hafalan, kurang dilengkapi dengan praktek-praktek di lapangan. Wardiman (2001) menyatakan bahwa strategi belajarnya kurang mendukung, mungkin tidak sesuai dengan materi yang diajarkan, mungkin terlalu monoton atau kurang bervariasi yang dapat menyebabkan turunnya hasil belajar fisika dan ilmu sains lainya seperti matematika dan biologi. Oleh karena itu, untuk mengatasi rendahnya hasil belajar kognitif siswa, guru harus mampu merancang strategi pembelajaran yang dapat menumbuhkan minat dan motivasi siswa serta memungkinkan keterlibatan siswa 
secara aktif dalam belajar. Salah satu strategi pembelajaran yang dapat digunakan guru dalam memotivasi dan memungkinkan keterlibatan siswa secara langsung dalam belajar adalah strategi pembelajaran inkuiri. Dengan menggunakan strategi pembelajaran inkuiri, siswa dihadapkan pada sebuah masalah yang tidak sengaja dibuat oleh guru atau hasil "rekayasa", sehingga siswa harus mengerahkan seluruh pikiran dan keterampilannya untuk mendapatkan temuan-temuan di dalam masalah itu melalui poses penelitian.

Selain penggunaan strategi pembelajaran yang tepat, salah satu solusi yang dapat digunakan untuk mengatasi rendahnya hasil belajar siswa adalah dengan menggunakan media pembelajaran interkatif dengan komputer. Menurut Lee (2000) alasan pemakaian komputer sebagai media pembelajaran adalah: pengalaman, motivasi, meningkatkan prestasi siswa, materi ajar yang otentik, interaksi yang lebih luas, lebih pribadi, tidak terpaku pada sumber tunggal, dan pemahaman global. Dengan media komputer, siswa menjadi termotivasi untuk belajar, dengan motivasi belajar yang tinggi akan mendorong siswa untuk berusaha mengerti suatu materi ajar hingga tuntas dan ini akan meningkatkan hasil belajar siswa.

Penerapan pembelajaran interaktif dengan komputer menjadi salah satu variasi pengguanan media pembelajaran modern yang mampu meningkatkan hasil belajar siswa. Pembelajaran dengan komputer berfungsi baik sebagai komunikasi dalam menyampaikan materi pelajaran. Penelitian Dori dan Barak (2003) menyimpulkan bahwa hasil belajar siswa yang dibelajarkan dengan media komputer lebih tinggi dari pada peserta didik yang menerima pembelajaran tanpa media komputer. Hasil penelitian Butar-butar (2007), menyimpulkan bahwa siswa yang diajarkan dengan program animasi komputer mendapat hasil belajar lebih tinggi dibandingkan dengam siswa yang diajar tanpa menggunakan program animasi komputer. Lebih lanjut hasil penelitian Sinurat (2008), menyimpulkan bahwa penggunaan media komputer meningkatkan hasil belajar siswa pada pokok bahasan struktur atom sebesar 21,38\%.

Untuk meningkatkan minat siswa terhadap mata pelajaran IPA, maka dalam pembelajarannya dapat digunakan media pembelajaran dan dikemas menjadi pelajaran yang menarik dan mudah dimengerti. Media pembelajaran dapat digunakan untuk membangun pemahaman dan penguasaan konsep pembelajaran. Beberapa media pembelajaran yang sering dipergunakan dalam proses belajar-mengajar diantaranya media cetak, elektronik, model, sketsa, peta dan diagram (Silalahi, 2009).

Menurut Rakhmat (2004), kemampuan komunikasi setiap individu akan mempengaruhi proses, aktivitas dan hasil belajar yang bersangkutan dan membentuk kepribadiannya. Hal ini berarti bahwa dalam proses pembelajaran di sekolah termasuk pembelajaran fisika perlu adanya komunikasi baik antara pendidik dengan peserta didik maupun komunikasi antar sesama peserta didik. Lebih lanjut menurut Max De Pree dalam Felber (2007), tidak ada usaha yang lebih penting untuk meraih keberhasilan dan hubungan antara manusia yang memuaskan daripada mempelajari seni berkomunikasi.

Pada prakteknya kegiatan pembelajaran di dalam kelas akan berlangsung dengan baik dan lancar jika ditunjang dengan komunikasi yang baik antara guru dengan siswa maupun antara sesama siswa. Penyampaian informasi maupun pesan bahan pelajaran juga dapat dikomunikasikan melalui kehadiran media pembelajaran, jika didukung dengan metode pembelajaran yang tepat. Menurut Arsyad (2005), pemilihan salah satu metode pembelajaran akan mempengaruhi jenis media pembelajaran yang sesuai meskipun ada berbagai aspek lain.

Terdapat beberapa definisi belajar menurut para ahli, Cronbach (1954) mengutarakan bahwa learning is shown by a change in behaviour as result of experience. Dalam hal ini dimaksudkan bahwa belajar adalah perubahan perilaku sebagai hasil dari pengalaman. Sehingga semakin banyak pengalaman seseorang maka akan berubah pula perilakunya. Dan menurut Skinner (2002) belajar adalah hubungan antara stimulus dan respon yang tercipta melalui proses tingkah laku. Seseorang telah dianggap belajar apabila mampu untuk menunjukkan perubahan tingkah laku. Menurut Gagne (1985) belajar adalah perubahan yang terjadi dalam kemampuan manusia setelah belajar terus menerus, dan bukan hanya disebabkan oleh proses pertumbuhan saja. Sementara menurut Morgan (1961) Belajar juga adalah suatu perubahan yang relatif menetap dalam tingkah laku sebagai akibat atau dari hasil pengalaman yang lalu. Sehingga proses yang terjadi pada siswa secara terus menerus akan 
memberikan dampak pada perubahan perilaku berdasarkan pengalaman yang telah dilalui.

Fisika merupakan salah satu bidang dalam Ilmu Pengetahuan Alam (IPA). Fisika merupakan ilmu yang lahir melalui langkahlangkah observasi, perumusan masalah, penyusunan hipotesis melalui eksperimen, penarikan kesimpulan serta penemuan teori dan konsep. Dapat dikatakan bahwa hakikat fisika adalah ilmu pengetahuan yang mempelajari gejala-gejala melalui serangkaian proses yang dikenal dengan proses ilmiah yang dibangun atas dasar sikap ilmiah dan hasilnya terwujud sebagai produk ilmiah yang tersusun atas tiga komponen terpenting berupa konsep, prinsip dan teori yang berlaku secara universal.

Reigeluth (1983) mengatakan bahwa hasil belajar secara umum dapat dikategorikan menjadi 3 (tiga) indikator, yaitu: (1) efektivitas pembelajaran, yang biasanya diukur dari tingkat keberhasilan (prestasi) peserta didik dari berbagai sudut; (2) efisiensi pembelajaran, yang biasanya diukur dari waktu belajar dan biaya pembelajaran; dan (3) daya tarik pembelajaran yang selalu diukur dari tendensi peserta didik ingin belajar terus menerus. Secara spesifik, hasil belajar adalah suatu kinerja (performance) yang diindikasikan suatu kapabilitas (kemampuan) yang diperoleh. Oleh karena itu, guru harus mampu sebaik mungkin mendesain suatu pembelajaran agar menarik perhatian peserta didik atau tidak monoton.

Gagne (1987) meninjau hasil belajar peserta didik yang harus dicapai dan proses belajar menuju ke hasil belajar dan langkahlangkah instruksional yang dapat diambil oleh guru dalam membantu peserta didik. Menurutnya ada 5 (lima) kategori hasil belajar; (1) informasi verbal; (2) kemahiran intelektual; (3) pengaturan kegiatan kognitif; (4) sikap, dan (5) keterampilan motorik. Untuk meningkatkan hasil belajar harus ada interaksi antara guru dan peserta didik. Pada dasarnya ada dua faktor utama yang sangat berpengaruh terhadap hasil belajar yaitu faktor dalam diri individu atau siswa (internal factor) serta faktor dari luar diri individu atau siswa (external factor).

Seels \& Richey (1994) menjelaskan bahwa strategi pembelajaran adalah spesifikasi dan mengurutkan kejadian dan aktivitas pembelajaran. Aktivitas pembelajaran meliputi penyajian materi, pemberian contoh, pemberian latihan serta pemberian umpan balik. Agar tujuan pembelajaran tercapai secara optimum, maka semua aktivitas harus diatur dengan mempertimbangkan karakteristik peserta didik, media dan situasi disekitar proses pembelajaran.

Dick \& Carey (1996) mengatakan bahwa strategi pembelajaran memuat lima komponen utama yaitu (1) Aktivitas pembelajaran pendahuluan, (2) Penyampaian informasi, (3) Partisipasi siswa, (4) Tes, dan (5) Kegiatan lanjutan. Suparman (1997) mendefinisikan strategi pembelajaran sebagai perpaduan dari: (1) Urutan kegiatan instruksional, (2) Metode Instruksional, (3) Media Instruksional, (4) Waktu yang digunakan dalam proses pembelajaran. Kedua definisi di atas pada prinsipnya lebih menekankan pada aspek komponen dan prosedur pembelajaran.

Hamalik (2004) mendefinisikan strategi pembelajaran adalah keseluruhan metode dan prosedur yang menitikberatkan pada kegiatan siswa dalam proses belajar mengajar untuk mencapai tujuan tertentu. Dalam konsteks strategi pembelajaran tersusun tujuan yang hendak dicapai, materi yang hendak dipelajari, pengalaman-pengalaman belajar dan prosedur evaluasi.

Berdasarkan berbagai penjelasan di atas, dapat disimpulkan bahwa strategi pembelajaran merupakan perpaduan dari urutan kegiatan, metode, media dan waktu yang digunakan oleh pengajar dan siswa dalam suatu proses pembelajaran untuk mencapai hasil yang telah ditentukan. Dalam menggunakan strategi pembelajaran hal utama yang harus diperhatikan adalah karakteristik pelajar. Seels \& Richey (1994), menyatakan bahwa karakteristik siswa adalah segi-segi latar belakang pengalaman pebelajar yang berpengaruh terhadap efektivitas proses belajarnya. Dick \& Carey (1996), menjelaskan bahwa pengembangan pembelajaran penting sekali mempertimbangkan karakteristik siswa untuk memilih pendekatan yang sesuai dalam kegiatan pembelajaran.

Heinich, Molenda, dan Russel (1985) mengemukakan istilah médium sebagai perantara yang mengantar informasi antara sumber dan penerima. Jadi, televisi, film, foto, radio, rekaman audio, gambar yang diproyeksikan, bahan-bahan cetakan, dan sejenisnya adalah media komunikasi. Apabila media itu membawa pesan-pesan atau informasi yang bertujuan intruksional atau mengandung maksud-maksud pembelajaran maka media itu disebut media pembelajaran. 
Istilah media yang merupakan bentuk jamak dari medium secara harfiah berarti perantara atau pengantar. Akan tetapi sekarang kata tersebut sudah digunakan baik dalam bentuk jamak maupun tunggal. AECT dalam Miarso (2007) mengartikan media sebagai segala bentuk dan saluran untuk proses transmisi informasi. Sedangkan Oslon dalam Miarso (2007) mendefinisikan medium sebagai teknologi untuk meyajikan, merekam, membagi dan mendistribusikan simbol dengan melalui rangsangan indra tertentu, disertai penstrukturan informasi.

Media pendidikan oleh Commision on Instrutional Technology (1970) diartikan sebagai media yang lahir sebagai akibat revolusi komunikasi yang dapat digunakan untuk tujuan pembelajaran disamping guru, buku teks, dan papan tulis. Gagne menyatakan bahwa media pendidikan adalah berbagai jenis komponen dalam lingkungan siswa yang dapat merangsang siswa untuk belajar. Briggs menyatakan bahwa media pembelajaran adalah sarana untuk memberikan perangsang bagi si belajar supaya proses belajar terjadi (Miarso, 2007).

Definisi lain dari media pembelajaran adalah sebagaimana yang terdapat dalam Susilana dan Riyana (2008) yang menyebutkan pengertian media yaitu: (1) Teknologi pembawa pesan yang dapat dimanfaatkan untuk keperluan pembelajaran, (2) Sarana fisik untuk menyampaikan isi/materi pembelajaran seperti buku, film, video, slide dan sebagainya, dan (3) Sarana komunikasi dalam bentuk cetak maupun pandang dengar, termasuk teknologi perangkat kerasnya. Media pembelajaran selalu terdiri atas dua unsur penting, yaitu unsur peralatan atau perangkat keras (hardware) dan unsur pesan yang dibawa (message/software).

Dick, Carey and Carey (2005) menyebutkan bahwa disamping kesesuaian dengan tujuan dan perilaku belajar, setidaknya ada empat faktor yang menjadi pertimbangan dalam pemilihan media, yaitu: (1) Ketersediaan sumber setempat, artinya bila media yang bersangkutan tidak tersedia pada sumber yang ada, maka harus dibeli atau dibuat sendiri; (2) Ketersediaan dana, tenaga dan fasilitas jika media tersebut dibeli atau diproduksi sendiri; (3) Tampilan media: yaitu yang menyangkut keluwesan, kepraktisan dan ketahanan media yang bersangkutan untuk waktu yang lama, artinya bisa digunakan dimana saja dengan peralatan yang ada disekitarnya, kapan saja serta mudah dijinjing dan dipindahkan; dan (4) Efektivitas biaya dalam jangka waktu yang lama. Cara lain dalam pemilihan media dapat menggunakan pola ASSURE model Heinich, Molenda dan Russel (1996), yang masingmasing huruf memiliki makna Analysis learner characteristics, State objectives, Select, modify or design materials, Utilitize materials, Require learner response dan Evaluate. Adapun prosedurnya adalah: 1) melakukan analisis terhadap karakteristik siswa, yaitu yang berkaitan dengan usia, pengalaman belajar sebelumnya, latar belakang keluarga, sosial budaya dan ekonomi, pengetahuan, skill dan sikap tertentuyang dimiliki siswa; 2) menentukan tujuan pembelajaran atau kompetensi yang hendak dicapai; 3) kegiatan memilih media, memodifikasi media yang sudah ada atau merancang sesuai kebutuhan; 4) memperhatikan dan mempelajari penggunaan media, hal ini dilakukan karena setiap media berbeda cara penggunaannya, lamanya waktu yang dibutuhkan dalam persiapan/pemasangan media; 5) mengamati respon siswa terhadap penggunaan media karena sasaran akhir dalam sebuah pembuatan media adalah harus dapat dipahami, dimengerti dan memudahkan siswa, fokus media tidak hanya pada kemasan saja namun lebih penting adalah kejelasan pesan; dan 6) tahap akhir adalah evaluasi yang diarahkan untuk mengukur penguasaan siswa terhadap materi yang diberikan dengan menggunakan media.

Interaktif pembelajaran dengan menggunakan komputer mengikuti tiga unsur yaitu: (1) Urutan-urutan intruksional yang dapat disesuaikan; (2) respon atau pekerjaan siswa; dan (3) Umpan balik yang dapat disesuaikan (Arsyad, 2007). Dalam pembelajaran menggunakan komputer seperti program exelearning, materi ajar dapat disajikan dalam bentuk tutorial dan disertai soal latihan pilihan ganda. Kegiatan belajar siswa menjadi interaktif, karena pada saat mengerjakan soal latihan, setiap alternatif jawaban disertai respon terhadap setiap jawaban siswa pada soal yang dikerjakan, apakah benar atau salah.

Program eXe merupakan singkatan dari elearning XHTML editor, yaitu sebuah program yang digunakan untuk membuat bahan ajar berbasis web yang dirancang untuk menyampaikan bahan ajar menjadi lebih mudah dan menarik (Purnomo, 2008). Pada program exelearning, guru dapat membuat bahan ajar 
berbasis web tanpa perlu mengetahui tentang HTML, bahkan lebih mudah dibanding web editor seperti Ms Frontpage. Keunggulan program exelearning yang lain adalah WYSIWYG (what you see is what you get) yakni apa yang kita rancang di layar hasilnya akan sama saat dipublikasi, gratis, merupakan aplikasi open source, standar e-learning (SCROM) dan dapat digunakan dalam Microsoft Windows atau linux (Warjana dan Razaq, 2009). Dalam program exelearning, guru hanya membuka halaman exelearning, kemudian mengisi dengan teks, gambar, video selanjutnya secara otomatis terbentuk daftar isi yang link ke semua halaman (Purnomo, 2007).

Media pembelajaran exelearning dapat dilakukan secara online dengan melakukan koneksi ke jaringan internet. Menurut Dabbagh dan Ritland (2005) pembelajaran online adalah sistem belajar yang terbuka dan tersebar dengan menggunakan perangkat pedagogi (alat bantu pendidikan), yang dimungkinkan melalui internet dan teknologi berbasis jaringan untuk memfasilitasi pembentukan proses belajar dan pengetahuan melalui aksi dan interaksi yang berarti. Media pembelajaran exelearning online dapat diartikan sebagai media yang dilengkapi dengan alat pengontrol yang dapat dioperasikan oleh pengguna (user), sehingga pengguna (user) dapat mengendalikan dan mengakses apa yang menjadi kebutuhan pengguna, misalnya mengunduh sumber-sumber untuk materi gaya pada pelajaran IPA. Keuntungan penggunaan media pembelajaran online adalah pembelajaran bersifat mandiri dan interaktivitas yang tinggi, mampu meningkatkan tingkat ingatan, memberikan lebih banyak pengalaman belajar, dengan teks, audio, video dan animasi yang semuanya digunakan untuk menyampaikan informasi, dan juga memberikan kemudahan menyampaikan, meng-update isi, mengunduh, para siswa juga bisa mengirim email kepada siswa lain, mengirim komentar pada forum diskusi, memakai ruang chat, hingga link video conference untuk berkomunikasi langsung.

Selanjutnya Dabbagh dan Ritland (2005) mengatakan ada tiga komponen pada pembelajaran online yaitu: (a) model pembelajaran, (b) strategi instruksional dan pembelajaran, (c) media pembelajaran online. Ketiga komponen ini membentuk suatu keterkaitan interaktif, yang didalamya terdapat model pembelajaran yang tersusun sebagai suatu proses sosial yang menginformasikan desain dari lingkungan pembelajaran online, yang mengarah ke spesifikasi strategi instruksional dan pembelajaran yang secara khusus memungkinkan untuk memudahkan belajar melalui penggunaan teknologi pembelajaran. Pada gambar 1 dapat dilihat keterkaiatan ketiga komponen tersebut.

Beberapa karakteristik media pembelajaran offline menurut Dabbagh dan Ritland (2005) adalah: (1) materi pembelajaran terpadu; (2) waktu pembelajaran tetap/waktu yang pasti; (3) dikontrol oleh guru/instruktur; (4) pembelajaran searah/linier; (5) sumber informasi yang dipilih telah diedit; (6) sumber informasi yang sudah tetap; dan (7) teknologi yang dipergunakan telah dikenal.

Ditinjau dari jenis interaksi dalam komunikasi, komunikasi dapat dibedakan atas tiga kategori yaitu: komunikasi interpersonal, komunikasi kelompok kecil, dan komunikasi publik. Menurut Muhammad (2007), komunikasi interpersonal adalah proses pertukaran informasi diantara seseorang dengan paling kurang seorang lainnya atau biasanya diantara dua orang yang dapat langsung diketahui balikannya. Soyomukti (2010), mengemukakan komunikasi interpersonal pada hakikatnya adalah interaksi antara seorang individu dan individu lainnya tempat lambanglambang pesan secara efektif digunakan, terutama dalam hal komunikasi antar-manusia menggunakan bahasa.

Sementara Devito dalam Soyomukti (2010), menyatakan bahwa komunikasi interpersonal adalah "the process of sending and receiving message between two persons, or among a small group of persons, with some effect and some immidiate feedback" (proses pengiriman dan penerimaan pesan-pesan antara dua orang atau diantara sekelompok kecil orangorang dengan beberapa efek dan beberapa umpan balik seketika). Berdasarkan definisi tersebut, komunikasi interpersonal bisa berlangsung antara dua orang yang saling bertemu, misalnya antara seorang mahasiswa dan dosen. Komunikasi interpersonal lebih efektif berlangsung jika berjalan secara dialogis, yaitu antara dua orang yang saling menyampaikan dan memberi pesan secara timbal balik.

Hafied Cagara (2007) dalam Jurnal Tabularasa mendefisinikan komunikasi interpersonal adalah proses komunikasi yang berlangsung di antara dua orang atau lebih secara 
tatap muka. Lebih lanjut Widjaja (2000) mengemukakan komunikasi interpersonal adalah proses pengiriman dan penerimaan pesan diantara dua orang atau sekelompok kecil orang dengan berbagai efek dan umpan balik. Lebih lanjut Muhammad (2007) mengemukakan, komunikasi interpersonal adalah proses pertukaran informasi diantara seseorang dengan paling kurang seorang lainnya atau biasanya diantara dua orang yang dapat langsung diketahui balikannya.

Rumusan masalah penelitian ini adalah: (1) Apakah hasil belajar siswa yang diajarkan dengan strategi pembelajaran inkuiri menggunakan media exelearning online lebih tinggi dibandingkan siswa yang diajarkan dengan strategi pembelajaran inkuiri menggunakan media exelearning offline?: (2) Apakah hasil belajar siswa yang memiliki komunikasi interpersonal terbuka lebih tinggi dibandingkan siswa yang memiliki komunikasi interpersonal tertutup?; (3) Apakah terdapat interaksi antara strategi pembelajaran inkuiri menggunakan media exelearning dan

\section{METODE}

Penelitian ini dilaksanakan di kelas VIII SMP Negeri 1 Lima Puluh dan SMP Negeri 2 Lima Puluh di Kecamatan Lima Puluh Kota Kabupaten Batubara. Populasi penelitian ini adalah seluruh siswa kelas VIII SMP Negeri di Kecamatan Lima Puluh yang terdiri atas 5 sekolah. Seluruh sampel memiliki karakteristik yang sama, artinya setiap kelas tidak memiliki siswa yang pernah tinggal kelas, tidak ada kelas unggulan, umur rata-rata siswa relatif sama, nilai rata-rata kelas relatif sama berdasarkan hasil ulangan harian, menggunakan kurikulum yang sama dan sama-sama sekolah SSN, sehingga seluruh kelas yang ada dapat diikutkan sebagai populasi dalam penelitian.

Penentuan sampel penelitian dilakukan secara acak kelas (cluster random sampling), yakni dengan mengundi kelas dari sekolah yang akan dijadikan sampel untuk melakukan perlakuan dengan strategi pembelajaran tertentu. Hasil pengundian didapat bahwa kelas VIII-A yang beranggotakan 39 orang siswa dari SMP Negeri 1 Lima Puluh sebagai kelas eksperimen pertama yang diterapkan strategi pembelajaran inkuiri menggunakan media exelearning offline, dan kelas VIII-B yang terdiri dari 39 siswa dari SMP Negeri 2 Lima Puluh sebagai kelas eksperimen kedua yang diterapkan strategi pembelajaran inkuiri menggunakan media exelearning online. Selanjutnya dari tiap kelas siswa dikelompokkan lagi menjadi dua kelompok berdasarkan komunikasi interpersonal yang dimiliki siswa, yaitu kelompok siswa yang memiliki komunikasi interpersonal terbuka dan kelompok siswa yang memiliki komunikasi interpersonal tertutup.

Metode yang digunakan dalam penelitian ini adalah metode quasi eksperimen dengan desain faktorial $2 \times 2$.

Tabel 1. Desain Penelitian dengan Faktorial $2 \times 2$

\begin{tabular}{ccc}
\hline Komunikasi & \multicolumn{2}{c}{ Strategi Pembelajaran $(\mathbf{A})$} \\
\hline Interpersonal $(\mathbf{B})$ & $\begin{array}{c}\text { Inkuiri }+ \text { Exelearning } \\
\text { Online }\left(\mathbf{A}_{1}\right)\end{array}$ & $\begin{array}{c}\text { Inkuiri }+ \text { Exelearning } \\
\text { Offline }\left(\mathbf{A}_{2}\right)\end{array}$ \\
\hline $\begin{array}{c}\text { Terbuka } \\
\left(\mathbf{B}_{1}\right)\end{array}$ & $\mu \mathrm{A}_{1} \mathrm{~B}_{1}$ & $\mu \mathrm{A}_{2} \mathrm{~B}_{1}$ \\
$(18$ siswa $)$ & $(23$ siswa $)$ \\
\hline $\begin{array}{c}\text { Tertutup } \\
\left(\mathbf{B}_{2}\right)\end{array}$ & $\begin{array}{c}\mu \mathrm{A}_{1} \mathrm{~B}_{2} \\
(21 \text { siswa) }\end{array}$ & $\begin{array}{c}\mu \mathrm{A}_{2} \mathrm{~B}_{2} \\
(16 \text { siswa })\end{array}$ \\
\hline
\end{tabular}

Keterangan :

$$
\begin{aligned}
& \text { A : Strategi pembelajaran inkuiri } \\
& \text { menggunakan media exelearning. } \\
& \text { B : Komunikasi interpersonal siswa } \\
& \mu \mathrm{A}_{1} \mathrm{~B}_{1} \text { : Rata-rata hasil belajar siswa yang } \\
& \text { diajarkan dengan strategi } \\
& \text { pembelajaran inkuiri menggunakan } \\
& \text { media exelearning online dan }
\end{aligned}
$$

memiliki komunikasi interpersonal terbuka

$\mu \mathrm{A}_{1} \mathrm{~B}_{2}$ : Rata-rata hasil belajar siswa yang diajarkan dengan strategi pembelajaran inkuiri menggunakan media exelearning online dan memiliki komunikasi interpersonal tertutup 
$\mu \mathrm{A}_{2} \mathrm{~B}_{1}$ : Rata-rata hasil belajar siswa yang diajarkan dengan strategi pembelajaran inkuiri menggunakan media exelearning offline dan memiliki komunikasi interpersonal terbuka

$\mu \mathrm{A}_{1} \mathrm{~B}_{2}$ : Rata-rata hasil belajar siswa yang diajarkan dengan strategi pembelajaran inkuiri menggunakan media exelearning offline dan memiliki komunikasi interpersonal tertutup

Teknik analisis data yang digunakan dalam penelitian ini adalah teknik analisis deskriptif dan analisis inferensial. Teknik analisis deskriptif dimaksudkan untuk mendeskripsikan data penelitian meliputi mean, standar deviasi, skor tertinggi, skor terendah, varians, median dan modus. Data yang telah diperoleh selanjutnya disajikan dalam bentuk tabel distribusi frekuensi menggunakan aturan Sturges dan dalam bentuk histogram.

Analisis statistik inferensi dilakukan untuk menguji hipotesis. Sebelum pengujian hipotesis, terlebih dahulu dilakukan uji prasyarat terhadap data yang dikumpulkan yaitu dengan menggunakan uji normalitas dan homogenitas. Uji normalitas dimaksudkan untuk menguji apakah data sampel yang diperoleh dari populasi memiliki sebaran yang berdistribusi normal dan pengujian normalitas data dilakukan dengan uji Lilliefors. Sedangkan uji homogenitas dimaksudkan untuk menguji apakah kelompokkelompok yang dijadikan sampel penelitian berasal dari populasi yang sama, artinya penyebarannya dalam populasi bersifat homogen. Uji homogentas data dilakukan dengan uji Fisher dan uji Burlett.

Setelah prasyaratan terpenuhi selanjutnya dilakukan pengujian hipotesis penelitian menggunakan teknik ANAVA dua jalur dengan faktorial $2 \times 2$. Hal ini dilakukan untuk menguji keberartian satu variabel atau kombinasi dua variabel terhadap variabel terikat. Apabila hasil statistik $F$ hitung pada taraf signifikansi $\alpha=5 \%$ terdapat perbedaan ratarata variabel terikat dari dua sampel sebagai akibat variabel bebas, maka analisis akan dilanjutkan dengan uji Tukey's.

Untuk pengujian hipotesis maka perlu dirumuskan hipotesis penelitian sebagai berikut:
a. $\mathrm{H}_{\mathrm{o}}: \mu \mathrm{A}_{1} \leq \mu \mathrm{A}_{2}$
$H_{a}: \mu A_{1}>\mu A_{2}$
b. $\mathrm{H}_{\mathrm{o}}: \mu \mathrm{B}_{1} \leq \mu \mathrm{B}_{2}$
$\mathrm{H}_{\mathrm{a}}: \mu \mathrm{B}_{1}>\mu \mathrm{B}_{2}$
c. $\mathrm{H}_{\mathrm{o}}: \mu \mathrm{A}><\mu \mathrm{B}=0$
$\mathrm{H}_{\mathrm{o}} \quad: \mu \mathrm{A}><\mu \mathrm{B} \neq 0$

\section{HASIL DAN PEMBAHASAN \\ Hasil}

Tabel 2. Rangkuman Tabulasi Data dengan Faktorial $2 \times 2$

\begin{tabular}{|c|c|c|c|c|c|c|c|c|c|}
\hline \multirow[b]{2}{*}{$\begin{array}{l}\text { Komunikasi } \\
\text { Interpersonal }\end{array}$} & \multicolumn{9}{|c|}{$\begin{array}{r}\text { Strategi + Media Pembelajaran } \\
\end{array}$} \\
\hline & \multicolumn{3}{|c|}{$\begin{array}{c}\text { Inkuiri + } \\
\text { Exelearning Online } \\
\text { (A1) }\end{array}$} & \multicolumn{3}{|c|}{$\begin{array}{c}\text { Inkuiri + Exelearning } \\
\text { Offline (A2) }\end{array}$} & \multicolumn{3}{|c|}{ Total } \\
\hline \multirow{4}{*}{$\begin{array}{l}\text { Terbuka } \\
\text { (B1) }\end{array}$} & $\mathrm{N}_{1}$ & $=$ & 18 & $\mathrm{~N}_{2}$ & $=$ & 23 & $\mathrm{NB}_{1}$ & $=$ & 41 \\
\hline & $\Sigma \mathrm{X}_{1}$ & $=$ & 435 & $\Sigma \mathrm{X}_{2}$ & $=$ & 506 & $\Sigma \mathrm{XB}_{1}$ & $=$ & 941 \\
\hline & $\Sigma \mathrm{X}^{2}{ }_{1}$ & $=$ & 10577 & $\Sigma \mathrm{X}_{2}^{2}$ & $=$ & 11276 & $\Sigma \mathrm{XB}^{2}{ }_{1}$ & $=$ & 21853 \\
\hline & $\overline{\mathrm{x}}_{1}$ & $=$ & 24,17 & $\bar{x}_{2}$ & $=$ & 22,00 & $\overline{\mathrm{x}}_{\mathrm{B} 1}$ & $=$ & 22,96 \\
\hline \multirow{4}{*}{$\begin{array}{l}\text { Tertutup } \\
\quad \text { (B2) }\end{array}$} & $\mathrm{N}_{3}$ & $=$ & 21 & $\mathrm{~N}_{4}$ & $=$ & 16 & $\mathrm{NB}_{2}$ & $=$ & 37 \\
\hline & $\Sigma \mathrm{X}_{3}$ & $=$ & 471 & $\Sigma \mathrm{X}_{4}$ & $=$ & 323 & $\Sigma \mathrm{XB}_{2}$ & $=$ & 794 \\
\hline & $\Sigma \mathrm{X}_{3}^{2}$ & $=$ & 10665 & $\Sigma X^{2}{ }_{4}$ & $=$ & 6587 & $\Sigma \mathrm{XB}^{2}{ }_{2}$ & $=$ & 17252 \\
\hline & $\bar{x}_{3}$ & $=$ & 22,43 & $\overline{\mathrm{x}}_{4}$ & $=$ & 20,19 & $\overline{\mathrm{x}}_{\mathrm{B} 2}$ & $=$ & 21,46 \\
\hline \multirow{4}{*}{ Total } & $\mathrm{NA}_{1}$ & $=$ & 39 & $\mathrm{NA}_{2}$ & $=$ & 39 & $\mathrm{~N}_{\mathrm{t}}$ & $=$ & 78 \\
\hline & $\Sigma \mathrm{XA}_{1}$ & $=$ & 906 & $\Sigma \mathrm{XA}_{2}$ & $=$ & 829 & $\Sigma \mathrm{X}_{\mathrm{t}}$ & $=$ & 1735 \\
\hline & $\Sigma \mathrm{XA}^{2}{ }_{1}$ & $=$ & 21242 & $\Sigma \mathrm{XA}^{2}{ }_{2}$ & $=$ & 17863 & $\Sigma X_{t}^{2}$ & $=$ & 39105 \\
\hline & $\overline{\mathrm{x}}_{\mathrm{A} 1}$ & $=$ & 23,23 & $\overline{\mathrm{x}}_{\mathrm{A} 2}$ & $=$ & 21,26 & $\bar{x}_{t}$ & $=$ & 22,24 \\
\hline
\end{tabular}

Secara keseluruhan hasil ANAVA untuk pengujian hipotesis dapat dilihat pada Tabel 3 berikut. 
Tabel 3. Rangkuman Hasil Pengujian Analisis Varians Dua Jalur

\begin{tabular}{lcrrrc}
\multicolumn{1}{c}{ Sumber Variasi } & dk & JK & $\mathbf{R K}=\mathbf{J K} / \mathbf{d k}$ & $\mathbf{F h}$ & $\mathbf{F t}_{\boldsymbol{\alpha}=\mathbf{0 , 0 5}}$ \\
\hline Antar Kolom (A) & 1 & 76,01 & 76,01 & 14,95 & 3,96 \\
Antar Baris (B) & 1 & 43,28 & 43,28 & 8,52 & 3,96 \\
Interaksi (AB) & 1 & 17,00 & 17,00 & 3,34 & 3,96 \\
Dalam & 74 & 376,08 & 5,08 & & \\
\hline Total Direduksi & 77 & 512,37 & - & & \\
\hline
\end{tabular}

Hasil Belajar antara Kelompok Siswa yang Diajarkan Strategi Pembelajaran Inkuiri Menggunakan Media Exelearning Online dan Media Exelearning Offline

Hipotesis statistik pertama dinotasikan sebagai berikut:

$\mathrm{H}_{\mathrm{o}}: \mu \mathrm{A}_{1} \leq \mu \mathrm{A}_{2}$

$\mathrm{H}_{\mathrm{a}}: \mu \mathrm{A}_{1}>\mu \mathrm{A}_{2}$

Hasil tabulasi dan analisis data, hasil belajar siswa yang diajarkan dengan strategi pembelajaran inkuiri menggunakan media exelearning online diperoleh rata-rata skor $=$ 23,23 lebih tinggi dibandingkan hasil belajar siswa yang diajarkan dengan strategi pembelajaran inkuiri menggunakan media exelearning offline dengan rata-rata skor $=$ 21,26 .

Selanjutnya dari hasil perhitungan pada Tabel 3, untuk varians antar kolom (strategi pembelajaran menggunakan media exelearning) diperoleh nilai $\mathrm{F}_{\text {hitung }}>\mathrm{F}_{\text {tabel }}$ yaitu 14,95 $>3,96$ pada taraf $\alpha=0,05$. Dengan demikian terima $\mathrm{H}_{\mathrm{a}}$ atau tolak $\mathrm{H}_{\mathrm{o}}$ sehingga disimpulkan bahwa hasil belajar siswa yang diajarkan dengan strategi pembelajaran inkuiri menggunakan media exelearning online lebih tinggi dibandingkan siswa yang diajarkan dengan strategi pembelajaran inkuiri menggunakan media exelearning offline.

Berdasarkan rata-rata skor yang diperoleh kedua kelompok sampel menunjukkan bahwa pembelajaran IPA dengan menggunakan strategi pembelajaran inkuiri menggunakan media exelearning online memberikan pengaruh sebesar 9,3\% lebih tinggi dibandingkan strategi pembelajaran inkuiri menggunakan media exelearning offline terhadap hasil belajar IPA siswa.

Hasil Belajar Siswa yang Memiliki Komunikasi Interpersonal Terbuka dengan Siswa yang Memiliki Komunikasi Interpersonal Tertutup Adapun hipotesis statistik kedua yang diuji adalah:

$\mathrm{H}_{\mathrm{o}}: \mu \mathrm{B}_{1} \leq \mu \mathrm{B}_{2}$
$\mathrm{H}_{\mathrm{a}}: \mu \mathrm{B}_{1}>\mu \mathrm{B}_{2}$

Hasil tabulasi dan analisis data diperoleh skor hasil belajar kelompok siswa yang memiliki komunikasi interpersonal terbuka rata-rata $=$ 22,95 lebih tinggi dibandingkan kelompok siswa yang memiliki komunikasi interpersonal tertutup dengan rata-rata skor $=21,46$.

Hasil perhitungan pada Tabel 4.16, untuk varians antar baris (komunikasi interpersonal) diperoleh nilai $\mathrm{F}_{\text {hitung }}>\mathrm{F}_{\text {tabel }}$ yaitu $8,52>3,96$ pada taraf $\alpha=0,05$. Dengan demikian terima $\mathrm{H}_{\mathrm{a}}$ atau tolak $\mathrm{H}_{\mathrm{o}}$ sehingga disimpulkan bahwa hasil belajar siswa yang memiliki komunikasi interpersonal terbuka lebih tinggi dibandingkan siswa yang memiliki komunikasi interpersona tertutup.

Berdasarkan rata-rata skor yang diperoleh kedua kelompok sampel menunjukkan bahwa komunikasi interpersonal terbuka memberikan pengaruh sebesar 6,9\% lebih tinggi dibandingkan komunikasi interpersonal tertutup terhadap hasil belajar IPA siswa

Interaksi Antara Strategi Pembelajaran Menggunakan Media Exelearning dan Komunikasi Interpersonal Terhadap Hasil Belajar Fisika Siswa

Adapun hipotesis statistik ketiga yang diuji adalah:

$\mathrm{H}_{\mathrm{o}}: \mu \mathrm{A}><\mu \mathrm{B}=0$

$\mathrm{H}_{\mathrm{a}}: \mu \mathrm{A}><\mu \mathrm{B} \neq 0$

Hasil perhitungan pada Tabel 3, untuk varians interaksi antara strategi pembelajaran menggunakan media exelearning dengan komunikasi interpersonal diperoleh nilai $\mathrm{F}_{\text {hitung }}<$ $F_{\text {tabel }}$ yaitu 3,34<3,96 pada taraf $\alpha=0,05$. Dengan demikian tolak $\mathrm{H}_{\mathrm{a}}$ atau terima $\mathrm{H}_{\mathrm{o}}$ sehingga disimpulkan tidak terdapat interaksi antara strategi pembelajaran menggunakan media exelearning dan komunikasi interpersonal siswa terhadap hasil belajar siswa.

Hasil pengujian hipotesis yang ketiga menyatakan tidak terdapat interaksi antara strategi pembelajaran menggunakan media exelearning dan komunikasi interpersonal 
terhadap hasil belajar siswa, sehingga tidak perlu dilakukan pengujian lanjutan untuk mengetahui rata-rata skor mana yang memberi pengaruh yang lebih tinggi terhadap hasil belajar siswa.
Hasil tabulasi dan analisis data rata-rata hasil belajar siswa berdasarkan interaksi antara strategi pembelajaran menggunakan media exelearning dan komunikasi interpersonal dapat dilihat pada Tabel 4.

Tabel 4. Rata-rata Hasil Belajar Siswa Interaksi Antara Strategi Pembelajaran dan Komunikasi Interpersonal Siswa

\begin{tabular}{ccc}
\hline $\begin{array}{c}\text { Komunikasi } \\
\text { Interpsersonal }\end{array}$ & \multicolumn{2}{c}{ Strategi Pembelajaran } \\
\hline $\begin{array}{c}\text { Terbuka } \\
\text { (B1) }\end{array}$ & $\begin{array}{c}\text { Inkuiri + Exelearning Online } \\
\text { (A1) }\end{array}$ & $\begin{array}{c}\text { Inkuiri + Exelearning } \\
\text { Offline (A2) }\end{array}$ \\
\hline $\begin{array}{c}\text { Tertutup } \\
\text { (B2) }\end{array}$ & 24,17 & 22,00 \\
\hline
\end{tabular}

Tabel 4 menunjukkan bahwa rata-rata hasil belajar kelompok siswa yang memiliki komunikasi interpersonal terbuka diajarkan strategi pembelajaran inkuiri menggunakan media exelearning online $(24,17)$ lebih tinggi dibandingkan hasil belajar ketiga kelompok siswa lainnya yaitu siswa yang memiliki komunikasi interpersonal tertutup diajarkan strategi pembelajaran inkuiri menggunakan media exelearning online $(22,43)$; siswa yang memiliki komunikasi interpersonal terbuka diajarkan strategi pembelajaran inkuiri menggunakan media exelearning offline $(22,0)$ maupun siswa yang memiliki komunikasi interpersonal tertutup diajarkan strategi pembelajaran inkuiri menggunakan media exelearning offline $(20,19)$.

Jika dilihat dari rata-rata hasil belajar siswa yang memiliki komunikasi interpersonal tertutup diajarkan strategi pembelajaran inkuiri menggunakan media exelearning online $(22,43)$ tidak berbeda secara signifikan dengan rata-rata hasil belajar siswa yang memiliki komunikasi interpersonal terbuka diajarkan strategi pembelajaran inkuiri menggunakan media exelearning offline $(22,0)$. Hal ini memberi indikasi bahwa kelompok siswa yang memiliki komunikasi interpersonal tertutup meskipun diajarkan dengan strategi pembelajaran inkuiri menggunakan media exelearning online tidak berarti hasil belajar yang diperolehnya lebih tinggi dibandingkan kelompok siswa yang memiliki komunikasi interpersonal terbuka jika diajarkan strategi pembelajaran inkuiri menggunakan media exelearning offline.
Sementara hasil belajar kelompok siswa yang memiliki komunikasi interpersonal terbuka diajarkan dengan strategi pembelajaran inkuiri menggunakan media exelearning offline $(22,0)$ dan kelompok siswa yang memiliki komunikasi interpersonal tertutup diajarkan strategi pembelajaran inkuiri menggunakan media exelearning online $(22,43)$ lebih tinggi dibandingkan hasil belajar kelompok siswa yang memiliki komunikasi interpersonal tertutup diajarkan dengan strategi pembelajaran inkuiri menggunakan media exelearning offline $(20,19)$.

\section{Pembahasan}

Kesimpulan dari hasil penelitian ini, sekaligus mendukung hasil penelitian Hidayat (2006), yang menyimpulkan bahwa penggunaan e-learning (pengiriman informasi online) dalam proses pembelajaran dapat meningkatkan motivasi belajar siswa sehingga menumbuhkan semangat siswa dalam mengikuti kegiatan pembelajaran yang dilaksanakan dan mampu mendorong siswa untuk mencapai hasil belajar yang lebih tinggi. Lebih lanjut hasil penelitian Minarti (2001), menyimpulkan bahwa pemanfaatan internet sebagai sumber belajar siswa memberikan pengaruh positif terhadap peningkatan hasil belajar sejarah siswa kelas XI program IPS SMA Negeri 1 Glagah Banyuwangi.

Kesimpulan dari hasil penelitian ini juga diperkuat dengan pendapat Dabbagh dan Ritland (2005) yang mengemukakan bahwa pembelajaran online sebagai sistem belajar yang terbuka dan tersebar dengan menggunakan perangkat paedagogi (alat bantu pendidikan), 
yang dimungkinkan melalui internet dan teknologi berbasis jaringan untuk memfasilitasi pembentukan proses belajar dan pengetahuan melalui aksi dan interaksi yang berarti. Pembelajaran dengan menggunakan media pembelajaran online menjadikan pembelajaran bersifat mandiri dan interaktivitas yang tinggi, mampu meningkatkan tingkat ingatan, memberikan lebih banyak pengalaman belajar, dengan teks, audio, video dan animasi yang semuanya digunakan untuk menyampaikan informasi, dan juga memberikan kemudahan menyampaikan, meng-update isi, mengunduh, para siswa juga bisa mengirim email kepada siswa lain, mengirim komentar pada forum diskusi, memakai ruang chat, hingga link video conference untuk berkomunikasi langsung.

Selama proses pembelajaran dari hasil pantauan peneliti, secara keseluruhan proses pembelajaran dengan strategi pembelajaran inkuiri menggunakan media exelearning online menjadikan siswa lebih aktif dalam kegiatan belajar, mulai dari merumuskan masalah, merumuskan hipotesis dan mencari, menemukan serta mengumpulkan data-data atau informasi dengan mengakses dan mengunduh materi dari berbagai sumber melalui internet untuk memecahkan masalah yang telah dirumuskan. Selama proses pembelajaran siswa juga aktif bertanya dan mengerjakan soal-soal yang ada secara acak sehingga tidak ada kesempatan untuk para siswa saling melihat atau mencontek siswa lainnya.

Sementara kelompok yang diajarkan dengan strategi pembelajaran inkuiri menggunakan media exelearning offline, siswa juga tampak aktif merumuskan masalah, hipotesis dan mengumpulkan data-data hanya dari informasi guru atau informasi-informasi yang telah ada pada program exelearning, siswa tidak dapat mengakses ataupun mengunduh melalui internet. Secara keseluruhan siswa aktif bertanya hanya seputar materi-materi yang ada dan mengerjakan soal-soal yang sama untuk setiap siswa (tidak diberikan secara acak) sehingga ada kemungkinan siswa saling berbagi informasi (mencontek) untuk menyelesaikan soal. Berdasarkan pengamatan di lapangan, tampak bahwa kelompok siswa yang diajarkan dengan strategi pembelajaran inkuiri menggunakan media exelearning online tampak lebih aktif dan antusias dalam memecahkan masalah belajar yang diberikan guru dibandingkan kelompok siswa yang diajarkan dengan strategi pembelajaran inkuiri menggunakan media exelearning offline.

Kesimpulan dari hasil penelitian ini juga didukung oleh pendapat Rakhmat (2004), yang mengemukakan bahwa kemampuan komunikasi setiap individu akan mempengaruhi proses, aktivitas dan hasil belajar yang bersangkutan dan membentuk kepribadiannya. Hal ini berarti dalam berbagai aktivitas sesesorang tidak terlepas dari aktivitas berkomunikasi. Komunikasi interpersonal merupakan komunikasi yang berlangsung di antara dua orang yang mempunyai hubungan yang mantap dan jelas, misalnya hubungan komunikasi guru dengan siswa maupun hubungan komunikasi siswa dengan sesama siswa. Seseorang yang memiliki komunikasi interpersonal terbuka dapat melakukan hubungan dan berbagai aktivitas termasuk dalam belajar, seperti bertanya, menjawab pertanyaan, mengajukan pendapat, menghargai ide atau pendapat orang lain dan lain sebagainya.

Komunikasi interpersonal berperan dalam mentransfer pesan/informasi dari seseorang kepada orang lain berupa ide, fakta, pemikiran serta perasaan. Oleh karena itu, komunikasi interpersonal merupakan jembatan bagi setiap individu termasuk siswa, di mana mereka dapat berbagi rasa, pengetahuan serta mempererat hubungan antara sesama individu dalam lingkungannya. Komunikasi interpersonal juga selalu menimbulkan saling pengertian atau saling mempengaruhi antara seseorang dengan orang lain.

Siswa dengan karakteristik komunikasi interpersonal terbuka adalah mereka yang mudah bergaul, aktif, optimis, bergairah, hidup semangat, memiliki sifat empati, simpati dan persuasi yang tinggi. Sedangkan karakteristik komunikasi interpersonal tertutup memiliki ciriciri yaitu sulit bergaul, senang menyendiri, acuh tak acuh, pesimis, pasif, pendiam dan sulit untuk beradaptasi dengan orang lain. Perbedaan karakteristik komunikasi interpersonal tersebut tentu saja memberikan pengaruh terhadap pencapaian hasil belajar siswa.

Hasil penelitian yang telah dilakukan menolak (tidak mendukung) hasil penelitian sebelumnya yang dilakukan Hendra (2011), yang menyimpulkan bahwa terdapat interaksi antara penggunaan media pembelajaran interaktif dan komunikasi interpersonal dalam mempengaruhi hasil belajar kimia siswa. Hasil penelitian Hendra (2011), diperoleh kelompok siswa yang memiliki komunikasi interpersonal 
terbuka memperoleh hasil belajar kimia lebih tinggi jika dibelajarkan dengan menggunakan media pembelajaran interakatif online daripada menggunakan media pembelajaran interaktif offline, sementara siswa yang memiliki komunikasi interpersonal tertutup lebih tinggi hasil belajarnya jika dibelajarkan dengan media pembelajaran interaktif offline daripada menggunakan media pembelajaran interaktif online.

Berdasarkan teori belajar Gestalt (insightful learning theory), belajar pada hakekatnya merupakan hasil dari proses interaksi antar individu dengan lingkungan sekitarnya. Belajar tidak hanya semata-mata merupakan suatu upaya untuk merespon suatu stimulus. Tetapi lebih dari itu, belajar dilakukan melalui berbagai kegiatan seperti mengalami, mengerjakan, dan memahami melalui proses atau learning by process (Sumiati, 2007). Pembelajaran yang baik dapat terjadi melalui suatu proses. Proses pembelajaran dapat berlangsung dengan baik apabila dilakukan dengan perencanaan yang baik dan tepat. Dalam perencanaan pembelajaran dibutuhkan kemampuan seorang guru untuk dapat memahami karakteristik siswa, materi yang diajarkan, model pembelajaran yang akan digunakan dan media pembelajaran yang dapat mendukung proses pembelajaran.

Selanjutnya konsep belajar Bruner dikenal sebagai belajar penemuan (discovery learning): (1) siswa berusaha sendiri untuk mencari pemecahan masalah serta pengetahuan yang menyertainya, menghasilkan pengetahuan yang benar-benar bermakna; dan (2) siswa hendaknya belajar melalui partisipasi secara aktif dengan konsep-konsep dan prinsip-prinsip agar memperoleh pengalaman dan melakukan eksperimen-eksperimen yang memungkinkan mereka memperoleh konsep baru. Lebih lanjut Seels \& Richey (1994) menjelaskan bahwa strategi pembelajaran adalah spesifikasi dan mengurutkan kejadian dan aktivitas pembelajaran. Aktivitas pembelajaran meliputi: penyajian materi, pemberian contoh, pemberian latihan serta pemberian umpan balik. Agar tujuan pembelajaran tercapai secara optimal, maka semua aktivitas harus diatur dengan mempertimbangkan karakteristik siswa, media dan situasi di sekitar proses pembelajaran. Hal ini memberi makna bahwa keberhasilan penerapan strategi pembelajaran bukan terletak pada langkah-langkah strategi yang digunakan tetapi juga dipengaruhi karakteristik siswa, media yang digunakan dan kondisi pembelajaran yang berlangsung.

Pada dasarnya, penggunaan strategi maupun media pembelajaran merupakan salah satu bentuk usaha guru dalam menyampaikan pesan atau informasi bahan pelajaran untuk mencapai tujuan belajar yang diharapkan yaitu agar siswa memperoleh hasil belajar yang lebih baik. Meskipun demikian, seperti yang telah dijelaskan sebelumnya bahwa keberhasilan penerapan strategi dan media pembelajaran haruslah mempertimbangkan karakteristik siswa termasuk komunikasi interpersonal siswa.

Bagi siswa yang memiliki komunikasi interpersonal yang tertutup, maka siswa tersebut akan sulit menerima maupun memahami materi yang disampaikan oleh guru di dalam kelas dan akan sulit memecahkan berbagai masalah yang diberikan guru meskipun diterapkan dengan strategi pembelajaran inkuiri menggunakan media pembelajaran exelearning. Hasil pantauan peneliti selama proses penelitian yang dilakukan, siswa yang memiliki komunikasi interpersonal tertutup cenderung acuh tak acuh dengan kegiatan yang terjadi di dalam kelas, pesimis, pasif, kurang berani berkomunikasi (bertanya maupun mengemukakan pendapat) meskipun telah diberikan kesempatan untuk bertanya, dan sulit beradaptasi dengan siswa lainnya saat diskusi kelompok, hal inilah yang menyebabkan siswa komunikasi interpersonal tertutup, sulit memperoleh hasil belajar yang optimal.

Sebaliknya siswa yang memiliki komunikasi interpersonal terbuka berdasarkan pantauan peneliti selama penelitian dilakukan, tampak selalu optimis, bergairah dan semangat dalam belajar, memiliki sifat empati, simpati dan persuasi yang tinggi, aktif dan dapat beradaptasi dalam setiap kegiatan pembelajaran yang dilakukan di dalam kelas, memliki rasa ingin tahu yang besar, berani mengkomunikasikan sesuatu yang masih kurang dipahami melalui pertanyaan yang diajukan muapun mengungkapkan pendapat saat dilakukan diskusi kelas. Siswa yang memiliki komunikasi interpersonal terbuka juga tampak mudah mengingat dan memahami materi yang disampaikan guru, sehingga ketika diberikan tugas atau dilakukan evaluasi siswa tersebut dapat memperoleh hasil belajar yang optimal. Jadi, pada dasarnya kemampuan berkomunikasi seseorang termasuk komunikasi interpersonalnya sangat menentukan keberhasilannya dalam belajar jika diberikan 
perlakuan yang sama. Tampak bahwa siswa yang memiliki komunikasi interpersonal terbuka lebih aktif dan percaya diri dalam setiap kegiatan pembelajaran dibandingkan siswa yang memiliki komunikasi interpersonal tertutup.

Berdasarkan hasil temuan penelitian dan pengujian hipotesis menunjukkan tidak adanya interaksi antara strategi pembelajaran inkuiri menggunakan media exelearning (online maupun offline) dan komunikasi interpersonal (terbuka maupun tertutup) terhadap hasil belajar IPA siswa. Namun demikian, dengan sedikit mengabaikan faktor interaksi pada komunikasi interpersonal yang dimiliki siswa, menunjukkan bahwa penggunaan strategi pembelajaran inkuiri menggunakan media exelearning online terbukti memberikan pengaruh yang lebih tinggi dan signifikan terhadap hasil belajar IPA siswa, dibandingkan penggunaan strategi pembelajaran inkuiri menggunakan media exelearning offline. Demikian halnya, dengan sedikit mengabaikan faktor interaksi pada penggunaan strategi pembelajaran inkuiri menggunakan media exelearning, menunjukkan bahwa komunikasi interpersonal terbuka yang dimiliki siswa memberi pengaruh yang lebih tinggi dan signifikan terhadap hasil belajar IPA siswa dibandingkan komunikasi interpersonal tertutup yang dimiliki siswa.

Dengan demikian, dari hasil temuan penelitian, pengujian hipotesis, teori dan hasilhasil penelitian yang relevan terbukti bahwa penggunaan strategi pembelajaran inkuiri menggunakan media exelearning (online maupun offline) dan komunikasi interpersonal (terbuka maupun tertutup) yang dimiliki siswa, secara terpisah berpengaruh terhadap hasil belajar IPA siswa, tetapi secara interaksi atau bersamaan diperoleh bahwa tidak ada interaksi pengaruh strategi pembelajaran inkuiri menggunakan media exelearning dan komunikasi interpersonal yang dimiliki siswa terhadap hasil belajar IPA siswa.

\section{PENUTUP}

Hasil belajar IPA siswa yang diajarkan dengan strategi pembelajaran inkuiri menggunakan media exelearning online lebih tinggi dibandingkan hasil belajar siswa yang diajarkan dengan strategi pembelajaran inkuiri menggunakan media exelearning offline. Strategi pembelajaran inkuiri menggunakan media exelearning online memberikan pengaruh sebesar lebih tinggi dibandingkan strategi pembelajaran inkuiri menggunakan media exelearning offline terhadap hasil belajar IPA siswa. Meskipun pengaruh tersebut tidaklah terlalu besar, tetapi kemampuan siswa setelah diajarkan strategi pembelajaran inkuiri menggunakan media exelearning online dalam menyelesaikan soal tes lebih baik dibandingkan kemampuan siswa setelah diajarkan dengan strategi pembelajaran inkuiri menggunakan media exelearning offline.

Hasil belajar IPA siswa yang memiliki komunikasi interpersonal terbuka lebih tinggi dibandingkan hasil belajar IPA siswa yang memiliki komunikasi interpersonal tertutup. Komunikasi interpersonal terbuka yang dimiliki siswa memberikan pengaruh sebesar dibandingkan siswa yang memiliki komunikasi interpersonal tertutup terhadap hasil belajar IPA siswa. Meskipun pengaruh tersebut tidak terlalu besar, tetapi siswa yang memiliki kemampuan interpersonal terbuka mampu menyelesaikan tes dengan baik dibandingkan siswa yang memiliki komunikasi interpersonal tertutup.

Tidak terdapat interaksi antara strategi pembelajaran inkuiri menggunakan media exelearning dan komunikasi interpersonal terhadap hasil belajar IPA siswa. Hal ini memberi indikasi bahwa siswa yang memiliki komunikasi interpersonal terbuka jika diajarkan dengan strategi pembelajaran inkuiri menggunakan media exelearning offline tidak berarti lebih baik dibandingkan siswa yang memiliki komunikasi interpersonal tertutup meskipun diajarkan dengan strategi pembelajaran inkuiri menggunakan media exelearning online.

\section{DAFTAR PUSTAKA}

AECT, (1987). Definisi Teknologi Pendidikan : Satuan Tugas Definisi dan Termologi, Jakarta: CV. Rajawali.

Akhmad, S., (2008). Pengertian Pendekatan, Strategi, Metode, Teknik, Taktik, dan Model Pembelajaran. http://psbpsma.org/content/blog/ pengertianpendekatan-strategi-metode-tekniktaktik-dan-model-pembelajaran

Amrullah, (2009). Pemanfaatan Game Fisika Sebagai Media Pembelajaran Dalam Upaya Mengatasi Rendahnya Motivasi Dan Hasil Belajar Fisika Siswa SMP Negeri 2 Gelumbang Kelas IX Pada Pokok Bahasan Kemagnetan http://www.blogspot.com/motivasi dan hasil belajar.htm. 
Arnas, A.L., (2010). Penggaruh Penggunaan Media Komik Terhadap Motivasi Dan Hasil Belajar Siswa Kelas XI Pada Pokok Bahasan Struktur Atom dan Sistem Periodik Unsur. Tesis tidak diterbitkan. Medan: Program Pascasarjana Unimed.

Arsyad, A., (2005). Media Pembelajaran, Jakarta: PT. Raja Grafindo Persada

Butar-Butar, R., (2007). Pengaruh Penggunaan Program Animasi Komputer Terhadap Motivasi Dan Hasil Belajar Kimia Siswa SMA Negeri di Kota Sibolga. Tesis tidak diterbitkan. Medan: Program Pascasarjana Unimed.

Devito, J.A., (2011). Komunikasi Antarmanusia Edisi Kelima. Alih Bahasa Maulana, Agus, Tangerang Selatan: Karisma.

Dick, W dan Carey, L., (2005). The Systematic Design Of Instruction Six Edition. USA: Pearson.

Dimyati dan Mudjiono, (2006). Belajar Dan Pembelajaran, Jakarta: Rineka Cipta.

Dori, Y.J., Barak, M. and Adir, N. 2003. A W"eb-based chemistry course as a means to foster freshmen learning. Journal of Chemical Education, 80(9), 1084-1092.

Elinawati, (2009). Pengaruh Strategi Pembelajaran dan Komunikasi Interpersonal Terhadap Hasil Belajar Pendidikan Agama Islam SMP Negeri 3 Rantau Utara Kabupaten Labuhan Batu. Tesis. Medan: Program Pascasarjana Unimed.

Farida H., (2008). Upaya Meningkatkan Motivasi Dan Hasil Belajar Siswa Kelas XI IPA Pokok Bahasan Ekskresi Melalui Metode Pembelajaran Konstektual Di Madrasah Aliyah Ma'Ahid Kudus Tahun Ajaran 2007/2008, Fakultas Keguruan Dan Ilmu Pendidikan Universitas Muhammadiyah Surakarta.

Felber, T. 2007. Kiat Praktis Komunikasi, Jakarta: Bhuana Ilmu Populer.

Ganti, M.H., (2010). Hubungan Motivasi Kerja, kecerdasan emosional dan komunikasi interpersonal dengan efektivitas manajemen kelas guru SMK di Kabupaten Simalungun, Tabularasa, Jurnal Pendidikan PPS Unimed.

Hamalik, O., (2001). Proses Belajar Mengajar, Jakarta: Bumi Aksara.

Hendra. 2011. Penggunaan Media Pembelajaran Interaktif dan Komunikasi Interpersonal Terhadap Hasil Belajar Kimia, Jurnal
Teknologi Pendidikan, http://hendrathjmr.blogspot.com/2011/10/jurnal.

Indra, M., (2010). Hasil Belajar Pengertian dan Definisi, $\quad$ http://www.blogspot. com/pengertian hasil belajar.htm.

Karimah A., (2009). Inovasi Pembelajaran Bahasa Indonesia Dengan Media Gambar, Bandar Lampung: Pascasarjana Teknologi Pendidikan Fakultas Keguruan dan Ilmu Pendidikan Universitas Lampung.

Lee.

file.upi.edu/Direktori/.../Materi_Media_P embelajaran.pdf.

Lindy, P., (2004). Bagaimana Memotivasi Anak Belajar, Jakarta: PT Gramedia Widiasarana.

Rakhmat, J., (2004). Psikologi Komunikasi, Bandung: Remaja Rosdakarya.

Sadiman, A., Raharjo, R., Haryono, A. dan Rahardjito, (1996). Media Pendidikan Pengertian, Pengembangan, dan Pemenfaatannya, Jakarta: PT Raja Grafindo Persada.

Salminingsih, (2010). Hubungan Pengetahuan Dan Penggunaan Media Pembelajaran Berbasis ICT dengan Efektivitas Pembelajaran, Tesis tidak diterbitkan, Surakarta: Prodi PKLH MU Pendidikan Geografi Program Pasca Sarjana Universitas Sebelas Maret.

Sanjaya, W., (2008). Pembelajaran Dalam Implementasi Kurikulum Berbasis Kompetensi, Jakarta: Kencana Prenada Media Group.

Sanjaya, W., (2008). Perencanaan dan Desain Sistem Pembelajaran, Jakarta: Kencana Prenada Media Group.

Sanjaya, W., (2008). Strategi Pembelajaran; Berorientasi Standar Proses Pendidikan, Jakarta: Kencana Prenada Media Group.

Silalahi, S.S., (2009). Media Petakonsep Dalam Pengajaran Laju Reaksi Pada Mahasiswa Tahun Pertama FPMIPA

Wahyu, P., (2010). Sekilas Penggunaan eLearning XHTML editor, http://wahyupur.blogspot.com.

Wardiman. 2001. Rencana Strategis Pendidikan Menengah Kejuruan, Jakarta: Departemen Pendidikan Nasional. 